\title{
Kawalan Undang-undang terhadap Kontrak Bentuk Seragam dalam Perjanjian Sewa Beli
}

\author{
(Legal Control of Standard Form Contracts in A Hire Purchase Agreement)
}

\author{
Siti NOORAFIZAH AZIZAN
}

\begin{abstract}
ABSTRAK
Kontrak bentuk seragam bukanlah isu baharu dalam kontrak pengguna kerana ia telah mengundang kepada pelbagai isu ketidakadilan dan ketidakseimbangan dari segi hak dan liabiliti pihak-pihak yang berkontrak. Kontrak bentuk seragam dianggap sebagai 'kontrak satu pihak' kerana terma dan syarat kontrak dibuat oleh satu pihak sahaja tanpa melalui proses perundingan dengan pihak-pihak yang lain dalam kontrak. Dalam kontrak kredit pengguna seperti kontrak sewa beli, kontrak bentuk seragam telah digunakan secara meluas. Isu-isu yang timbul dalam kontrak sewa beli yang berbentuk seragam adalah berkait dengan terma tidak adil dan fasal pengecualian yang dimasukkan dalam kontrak. Pengguna akhirnya menjadi pihak yang menanggung kerugian kerana hak-hak mereka telah dihadkan melalui terma-terma kontrak oleh pihak penyedia perkhidmatan. Objektif artikel ini adalah untuk menganalisis sejauh manakah pengguna dilindungi di bawah undang-undang apabila memasuki kontrak sewa beli berbentuk seragam. Walaupun Akta Sewa Beli 1967 dan Akta Pelindungan Pengguna 1999 menyediakan peruntukan bertujuan untuk melindungi pengguna daripada terma-terma tidak adil dan fasal pengecualian dalam kontrak, namun masih terdapat kelompangan dan kelemahan undang-undang yang perlu diberi perhatian bagi memantapkan aspek perlindungan pengguna.
\end{abstract}

Kata Kunci: Kontrak bentuk seragam, kontrak sewa beli, pengguna, terma tidak adil, fasal pengecualian

\section{ABSTRACT}

The issue of standard form contracts is not a new problem in consumer contracts. It has invoked various issues of injustice and imbalance in terms of the rights and liabilities of the contracting parties. Standard form contracts are considered as 'one-sided contracts' because the terms and conditions of the contract are set by one of the parties, without any negotiation process with the other parties in the contract. In consumer credit contracts such as hire purchase agreements, standard form contracts have been widely used. Issues arising in the standard form hire purchase agreements are related to unfair contract terms and exclusion clauses stipulated in the contracts. Consumers are ultimately at risk because their rights have been limited by the terms of the contract, imposed by the service provider. The objective of this article is to analyse to what extent do consumers are protected under the law when entering into a standard hire purchase agreement. Although the Hire Purchase Act 1967 and the Consumer Protection Act 1999 provide provisions to protect consumers from unfair terms and exclusion clauses in the contract, there are still loopholes and weaknesses in the existing laws that need to be addressed in order to safeguard the interest of the consumers.

Keywords: Standard form contract, hire purchase agreement, consumer, unfair contract term, exclusions clause

\section{PENGENALAN}

Kontrak bentuk seragam merupakan suatu corak transaksi pengguna dan komersial yang biasa sejak kebelakangan ini, ${ }^{1}$ didraf oleh pihak yang mempunyai kuasa dan kedudukan yang lebih baik dalam perundingan. ${ }^{2}$ Terma-terma kontrak telah tersedia dan dicetak dalam dokumen, tanpa membuka ruang kepada sebarang rundingan pihak-pihak yang berkontrak. Lantaran itu, kontrak pengguna bentuk seragam disifatkan sebagai "perundangan persendirian" yang tidak demokratik yang dikenakan terhadap pengguna oleh organisasi persendirian yang besar. ${ }^{3}$ Sedar atau tidak, hakikatnya pengguna berhadapan dengan kontrak bentuk seragam dalam hampir setiap transaksi kontrak yang dimasuki setiap hari. Antaranya, kontrak pembelian tiket perkhidmatan pengangkutan seperti kapal terbang, kereta api dan bas, tiket wayang, pembelian barangan serta 
kontrak perkhidmatan yang lain. Malahan, pemakaian kontrak bentuk seragam turut diperluas kepada kontrak-kontrak pengguna yang lain seperti kontrak insurans dan kontrak kredit.

Dari sudut yang lain, kontrak bentuk seragam mempunyai justifikasinya yang tersendiri. Peralihan cara dan trend pengeluaran barangan kepada yang bersifat massa dan besar-besaran seperti yang berlaku pada hari ini, turut membawa perubahan kepada corak kontrak pengguna. Kepelbagaian teknik pemasaran dan penjualan barangan serta perkhidmatan dalam era globalisasi telah membawa suasana perdagangan yang moden dan canggih. Oleh itu, pertemuan secara fizikal antara pihak penjual dengan pembeli untuk berunding dan menyetujui terma kontrak yang bakal dimasuki, bukan lagi dianggap sebagai sesuatu yang penting. Perubahan ini turut dikaitkan dengan keperluan terhadap suatu kaedah kontrak yang cepat, menjimatkan masa serta kos kewangan. Isu kontrak bentuk seragam adalah isu kos transaksi. ${ }^{4}$ Hal ini kerana proses perundingan secara individu melibatkan pembaziran masa, mahal dan tidak menguntungkan mana-mana pihak dan peningkatan kos ini mungkin akan dialihkan kepada pengguna. ${ }^{5}$ Fenomena kontrak bentuk seragam merupakan cabaran yang terhasil daripada perubahan sosioekonomi pengguna yang dikepilkan dengan perkembangan era teknologi pada masa ini. ${ }^{6}$ Howells beranggapan bahawa perubahan inilah yang memperkenalkan kontrak berbentuk seragam, yang seharusnya diterima oleh semua pihak yang berurusan dalam organisasi berskala besar. ${ }^{7} \mathrm{Hal}$ ini kerana perubahan yang berlaku dalam pasaran pengguna kepada pengeluaran dan penghasilan barangan dalam kuantiti yang banyak menyebabkan barang yang dihasilkan adalah sama dan seragam. Bagi menjimatkan kos, peniaga menggunakan kontrak bentuk seragam ke atas produk yang dihasilkan, dengan menerima pakai terma-terma seragam, yang dimasukkan oleh peniaga tanpa melalui proses perundingan dengan pengguna.

Fenomena kontrak bentuk seragam turut berlaku dalam perkhidmatan penyediaan kredit. Faktor ini turut didorong oleh kepesatan yang berlaku dalam industri kredit pengguna pada hari ini, ditambahkan lagi dengan pelbagai produk kredit yang ditawarkan di pasaran menyebabkan rundingan secara individu bagi menghasilkan kontrak yang berbeza dengan setiap pengguna menjadi sukar dan tidak lagi sesuai untuk dilaksanakan.

\section{PERJANJIAN SEWA BELI: KONTRAK BENTUK SERAGAM}

Kontrak sewa beli merupakan kontrak antara tuan punya dengan penyewa, disediakan oleh tuan punya, iaitu pihak yang menyediakan perkhidmatan kredit, yang pada kebiasaannya terdiri daripada pihak bank atau institusi kewangan. Keadaan ini telah mendorong sesuatu perjanjian sewa beli dibuat dengan mengikut kehendak dan keperluan pihak tuan punya, tanpa melalui proses perundingan dan persetujuan daripada penyewa. Penyewa tiada pilihan, melainkan terpaksa bersetuju dengan terma-terma yang telah ditetapkan oleh tuan punya sekiranya ingin meneruskan kontrak tersebut. Inilah senario yang sering kali dihadapi oleh pengguna apabila memasuki kontrak sewa beli yang merupakan kontrak berbentuk seragam.

Teori dan prinsip-prinsip asas dalam undang-undang kontrak bagi membentuk kontrak yang adil kepada semua pihak telah terjejas dengan kewujudan dan amalan kontrak bentuk seragam. Prinsip "kebebasan berkontrak" menjadi landasan utama dalam pembentukan sesuatu kontrak. Pihak-pihak seharusnya bersetuju dan bebas dalam menentukan terma kepada kontrak yang bakal dimasuki melalui proses perundingan yang seimbang. Kemunculan kontrak jenis ini yang dibentuk atas sifatnya yang berat sebelah dari awal penyediaannya telah mengancam kestabilan dokrin kebebasan berkontrak apabila kuasa perundingan dan tawar- menawar antara kedua-dua pihak telah dinafikan. Dalam kontrak kredit, konsep kebebasan berkontrak tidak membawa erti yang besar kepada pengguna kerana pengguna biasanya berada dalam keadaan terdesak untuk membuat pinjaman dan tidak menghiraukan akan terma dan syarat yang dikenakan. Oleh itu, kesempatan ini diambil oleh pihak lain untuk menindas pengguna akibat sikap tidak ambil kisah tersebut.

Penyediaan terma oleh satu pihak boleh mengundang pelbagai isu ketidakadilan dan ketidakseimbangan dari segi hak dan liabiliti pihak-pihak yang berkontrak. Antara isu yang dimaksudkan adalah terma tidak adil dan fasal pengecualian yang dimasukkan dalam kontrak pengguna. ${ }^{8}$

\section{Terma tidak adil dalam kontrak sewa beli}

Menurut Atiyah: ${ }^{9}$

A term which has not been individually negotiated is an unfair term if contrary to the requirements of good 
faith, it causes a significant imbalance in the rights and obligations of the parties to the detriment of the consumer, taking into account the nature of the goods and services, and the circumstances attending the making of the contract.

Berdasarkan ungkapan di atas, adalah jelas bahawa terma kontrak dianggap sebagai tidak adil apabila ia bertentangan dengan keperluan suci hati, menyebabkan ketidakseimbangan yang ketara terhadap hak-hak dan obligasi pihak-pihak dan menyebabkan kerugian kepada pengguna. ${ }^{10}$ Fasal-fasal yang terdapat dalam kontrak bentuk seragam biasanya terdiri daripada fasal atau terma berat sebelah yang tidak adil kepada pengguna serta memberikan kesan terhadap hak mereka. Dalam kontrak bentuk seragam, tugas maksimum akan diletakkan terhadap pengguna, manakala tanggungjawab yang minimum dikenakan terhadap pembekal. ${ }^{11}$ Hanya pengguna yang berpengetahuan tinggi yang akan meminda atau menolak terma yang dicadangkan oleh peniaga $^{12}$ dan ini merupakan petanda kepada keadaan kuasa tawar-menawar yang tidak seimbang. ${ }^{13}$ Mac Kinnon, L.J. dalam kes South Bedfordshire Electrical Finance Ltd $v$. Bryant $^{14}$ yang melibatkan transaksi sewa beli menyatakan bahawa:

... if anybody is so foolish as to enter into such an agreement as this, I do not know that his case can be considered harsh.

Manakala melalui kes Campbell Discount Co. Ltdv Bridge, ${ }^{15}$ Harman, L.J., turut meluahkan kekesalannya berhubung dengan kontrak bentuk seragam seperti yang berikut:

The uneasy feeling that I have that the position of the law as it stands is not satisfactory, I rather deprecate the attempt to urge the court on what are called equitable principles to dissolve contracts which are thought to be harsh, or which have turned to be disadvantageous to one of the parties.

Dalam perjanjian sewa beli, antara contoh terma tidak adil yang memberikan kelebihan kepada pihak tuan punya adalah:

a. The hirer hereby confirms that he has not expressly or by implication made known to the owner or any dealer or to any, servant or agent of the owner or the dealer any particular purpose for which the goods are required. b. The hirer warrants to the owner that the hirer has relied on the hirer's own skill own and judgment in selecting the goods.

c. For the purpose of taking possession of the goods, the owner or any servant and agent of the owner shall be entitled to enter upon the premises occupied by or in my possession in which the goods may be found.

d. The hirer hereby acknowledges and confirms that this agreement has been duly completed prior to the execution hereof by the hirer and that he has read and understood the contents herein.

e. The hirer shall for the duration of this agreement, at his own cost and expense keep the goods in good order repair and condition to the satisfaction of the owner and shall indemnify the owner against all loss, claims and expenses arising out of any damage to the goods however caused.

Fasal-fasal yang dimasukkan sebagai terma kontrak ini secara jelas bertujuan untuk meletakkan beban, obligasi dan liabiliti secara maksimum kepada pengguna. Pengguna mempunyai ruang dan peluang yang sedikit di sisi undang-undang dan terpaksa tunduk dan akur kepada terma-terma tidak adil yang secara jelas bersifat berat sebelah. Fasal-fasal yang dimasukkan bukan sahaja sukar difahami maksudnya, malah kebiasaannya dicetak dalam bentuk huruf kecil, tidak jelas dan sukar dibaca. Bagi mengelakkan sebarang tindakan sivil, kontrak tidak adil akan didraf secara mengelirukan kerana tiada peruntukan yang jelas di bawah Akta Kontrak 1950 boleh dirujuk bagi menjadikan kontrak tersebut batal atau boleh batal. ${ }^{16}$

2. Fasal pengecualian dalam kontrak sewa beli

Fasal pengecualian adalah fasal yang mengecualikan atau mengubah obligasi dalam kontrak, yang memberikan kesan terhadap keadaan dan skop pelaksanaan kontrak oleh pihak-pihak. ${ }^{17}$ Penggunaan fasal pengecualian merupakan satu fenomena biasa dalam kontrak bentuk seragam, bertujuan untuk mengetepikan obligasi serta mengelakkan liabiliti. Borrie ${ }^{18}$ berpendapat, memasukkan fasal pengecualian dalam kontrak bentuk seragam merupakan cara termurah bagi 
mengelakkan liabiliti. Fasal pengecualian bukan sahaja menjadikan pihak yang telah memungkiri kontrak tidak boleh diambil tindakan, tetapi juga menyebabkan pihak yang tidak bersalah melepaskan haknya terhadap remedi. ${ }^{19}$

Akta Sewa Beli $1967^{20}$ secara jelas membenarkan tuan punya memasukkan fasal pengecualian untuk menafikan liabiliti ke atas obligasi mematuhi terma tersirat ${ }^{21}$ bagi barangan terpakai. Syarat tersirat kualiti boleh niaga dan barangan sesuai untuk tujuan kegunaannya ${ }^{22}$ boleh dielakkan oleh tuan punya dengan syarat barang dalam perjanjian ialah barang terpakai dan pengecualian tersebut haruslah dinyatakan secara jelas dan ditandatangani oleh penyewa. Oleh itu, dalam perjanjian sewa beli, tuan punya sering kali memasukkan fasal yang berikut:

WHERE THE GOODS ARE IN THE ABOVE SCHEDULES STATED TO BE SECOND-HAND, ALL CONDITIONS AND WARRANTIES AS TO MERCHANTABLE QUALITY AND AS TO FITNESS AND SUITABILITY AS REQUIRED UNDER SECTION 7(2) OF THE HIRE PURCHASE ACT 1967 ARE HEREBY EXPRESSLY NEGATIVED AND THE HIRER HEREBY ACKNOWLEDGE THAT THE STATEMENT THAT THE GOODS ARE SECOND-HAND AND THAT SUCH CONDITIONS AND WARRANTIES ARE EXPRESSLY NEGATIVED HAVE BEEN BROUGHT TO THE HIRER'S NOTICE.

Dengan kelonggaran yang diberikan oleh undang-undang ini, maka ada penjual yang mengambil kesempatan dengan mendapatkan kenderaan potong, disambung semula dan kemudian dijual kepada pengguna melalui kemudahan kredit sewa beli dengan harga yang murah. ${ }^{23}$ Tindakan ini bukan sahaja menipu pengguna, tetapi apa yang lebih penting ialah ia membabitkan isu keselamatan pengguna. Kesannya, barangan yang didapati tidak selamat dan membahayakan pengguna turut ditawarkan melalui kredit sewa beli. Selain fasal pengecualian yang dibenarkan oleh undang-undang, beberapa fasal pengecualian lain yang sering kali dimasukkan oleh tuan punya dalam perjanjian sewa beli bagi mengetepikan obligasi adalah seperi yang berikut:

a. That the owner shall not be responsible or liable in any way whatsoever for any property or article alleged by the hirer to have been left in the repossessed or returned goods. b. The hirer agrees that the owner will have no responsibility or liability for any loss or damage to any property of the hirer.

c. Information relating to the facility may be forwarded by the owner to any credit bureau or agencies approved by Bank Negara Malaysia, any other bureau approved by the Association of Finance Companies and other third parties who may be entering into prospective transactions with the hirer or any other person and in so doing I shall not hold the owner responsible or liable in any way for any loss or damage that may arise directly or indirectly to the hirer or any other person.

Persoalannya, sejauh manakah kelonggaran dan kebebasan yang diberikan kepada tuan punya bagi mengecualikan liabiliti di bawah perjanjian sewa beli? ASB 1967 memperuntukkan mana-mana peruntukan yang mengecualikan, mengubah atau mengehadkan peruntukan Akta adalah terbatal dan tiada kesan melainkan jika ia dibenarkan oleh Akta. ${ }^{24}$ Berdasarkan peruntukan ini, adalah jelas bahawa fasal yang tidak bertentangan dengan peruntukan atau keperluan ASB 1967 adalah sah dan terpakai.

\section{KAWALAN PERUNDANGAN}

Persoalan yang sering dibangkitkan dalam isu kontrak bentuk seragam adalah adakah perlu undang-undang campur tangan bagi mengawal terma-terma ini? Sekiranya perlu, adakah ini bertentangan dengan prinsip kebebasan berkontrak serta akan menghalang kebebasan pihak-pihak yang berkontrak untuk menentukan terma-terma kontrak mereka? Ramsay ${ }^{25}$ berpandangan bahawa peraturan bagi mengawal terma-terma kontrak adalah perlu dan rasional kepada keperluan ini adalah atas faktor ketidakseimbangan kuasa tawar-menawar yang secara meluas berlaku pada tahun 1960-an dan 1970-an yang mana pengguna tidak mampu untuk melindungi diri daripada kuasa ini. Faktor ketidakseimbangan kuasa tawar-menawar turut mempengaruhi The Crowther Report on Consumer Credit yang mana konsep ini telah digunakan dalam menjustifikasikan kertasb cadangan perlindungan pengguna:

6.1.2 It has long been recognized that freedom of contract has little meaning in consumer 
transactions. Bargaining power lies with the supplier and this is particularly the case where the transaction involves the extension of credit. There are various reasons for this....

i. In the case of borrowing, the debtor's need may be such that he is constrained to borrow on whatever terms he can get.

ii. Even where the debtor has no pressing liabilities to discharge, the acquisitive urge is strong and may override prudence, particularly if the debtor's appetite is whetted by enthusiastic salesman. The consumer's vulnerability is greatly enhanced by the attraction of easy terms.

iii. The lack of information may make it difficult for the consumer to discover the draw-backs in the proposed transaction and the alternative opportunities that may be open to him. In short, all the expertise is on one side.

iv. The utility of such information as is available is likely to be diminished by pressure at the point of sale.

v. The modern standard-term contract is drawn almost entirely from the view point of the supplier of goods or services and thus tends to impose maximum duty on the consumer and minimum responsibilities on the supplier.

vi. It is difficult, if not impossible, for the consumer to procure an alternative to the standard-term contract even if he did has the tenacity to read it through from beginning to end. He would be told to take it or leave it....... ${ }^{26}$

Sehingga kini, Malaysia tidak mempunyai statut khusus bagi mengawal terma-terma dalam kontrak. Sejak sekian lama, sebarang pertikaian berhubung dengan terma tidak adil dalam kontrak, mahkamah akan memutuskannya berdasarkan prinsip-prinsip common law. Akta Pelindungan Pengguna 1999 (APP 1999), pada peringkat awal penggubalannya tidak menyediakan sebarang peruntukan berkaitan dengan terma dalam kontrak bagi melindungi pengguna. Begitu juga dengan Akta Kontrak 1950 yang tidak menyentuh berkaitan dengan perkara tersebut. Mahkamah di Malaysia dilihat sebagai bertindak perlahan untuk mengiktiraf doktrin ketidakseimbangan kuasa tawar-menawar (inequality of bargaining power). ${ }^{27}$ Hanya dalam beberapa keadaan tertentu sahaja mahkamah akan mempertimbangkan kesahan limitasi atau fasal pengecualian yang terkandung dalam kontrak pengguna. ${ }^{28}$

Sehinggalah pada tahun 2010, atas desakan pelbagai pihak bagi melindungi pengguna, parlimen Malaysia telah meluluskan pindaan ke atas Akta Pelindungan Pengguna 1999 melalui Akta Pelindungan Pengguna (Pindaan) 2010, Bahagian IIIA - Terma Kontrak Tidak Adil ${ }^{29}$ sebagai satu langkah kawalan ke atas kontrak bentuk seragam. ${ }^{30}$ "Kontrak bentuk seragam" ditafsirkan sebagai kontrak pengguna yang telah dirangka untuk kegunaan umum dalam sesuatu industri, sama ada atau tidak kontrak itu berbeza daripada kontrak yang pada kebiasaannya digunakan dalam industri itu, manakala "terma tidak adil" adalah terma dalam kontrak pengguna, dengan mengambil kira semua hal keadaan, menyebabkan ketidakseimbangan yang signifikan dalam hak dan tanggungjawab pihak-pihak di bawah kontrak itu sehingga merugikan pengguna. ${ }^{31}$ Menariknya tentang peruntukan Bahagian IIIA ini, terma tidak adil telah dikategorikan kepada ketidakadilan tatacara dan inti pati (substantive), dan pembahagian sebegini merupakan yang pertama dan tidak pernah diperkenalkan di mana-mana negara sebelum ini. ${ }^{32}$ Dengan adanya peruntukan melalui Bahagian IIIA, mahkamah atau tribunal berkuasa untuk mengistiharkan sesuatu terma tidak adil dalam kontrak sebagai batal atau tidak boleh dikuatkuasakan. ${ }^{33}$ Selain remedi sivil, Bahagian IIIA turut menjadikan kesalahan penggunaan terma tidak adil sebagai suatu kesalahan jenayah yang berhadapan dengan penalti. ${ }^{34}$

Melalui Bahagian IIIA APP 1999, penyewa yang merupakan seorang pengguna ${ }^{35}$ dalam kontrak sewa beli boleh mendapat perlindungan kerana APP 1999 turut terpakai kepada kontrak pembekalan barang melalui sewa beli. ${ }^{36}$ Namun begitu, Bahagian IIIA mempunyai beberapa kelemahan dan kekaburan yang menimbulkan beberapa persoalan. Pertama, menjadi satu-satunya negara yang membahagikan ketidakadilan terma kepada tatacara dan substantif, sudah pasti mengundang kepada cabaran yang besar. Tanggungjawab besar dipikul oleh mahkamah dan tribunal untuk membezakan serta menentukannya. Kedua-dua jenis ketidakadilan ini kadangkala bertindih dan sukar untuk dibezakan. ${ }^{37}$

Selain itu, seksyen 24G memberikan kuasa kepada mahkamah atau tribunal untuk 
mengistiharkan sesuatu terma tidak adil dalam kontrak sebagai batal atau tidak boleh dikuatkuasakan. Selain remedi sivil, seksyen 24I turut menjadikan kesalahan penggunaan terma tidak adil sebagai suatu kesalahan jenayah yang berhadapan dengan penalti. Rasional pembahagian ini turut dipersoalkan atas dasar kesannya, iaitu kesan sivil dan penalti jenayah yang sama diperuntukkan kepada terma tidak adil sama ada tatacara mahupun substantif. ${ }^{38}$ Kewajaran menjadikan kesalahan penggunaan terma dalam kontrak sebagai suatu kesalahan yang berhadapan dengan penalti jenayah juga turut diperdebatkan. ${ }^{39}$ Dari aspek yang lain, seksyen 24G juga dianggap amat mengelirukan dan bercanggah dengan prinsip asas undang-undang kontrak kerana dalam undang-undang kontrak, pengertian kontrak yang "tidak boleh dilaksanakan" dan kontrak "batal" memberikan implikasi yang berbeza. ${ }^{40}$ Kedua-dua peruntukan ini bercanggah dan menjadikan kesan terhadap kontrak tidak adil yang bersifat tatacara dan substantif yang wujud dalam kontrak pengguna tidak jelas. ${ }^{\mathrm{Ss}}$

Selain itu, ketiadaan badan atau agensi khas di Malaysia yang bertindak sebagai pemantau kepada terma-terma tidak adil yang digunakan dalam kontrak pengguna khususnya kontrak umum yang biasanya dipakai oleh industri terhadap pengguna, merupakan suatu lagi kelemahan Bahagian IIIA. Jika dibandingkan dengan negara lain seperti United Kingdom dan Australia, kewujudan agensi pemantau ${ }^{42}$ yang diberi kuasa pentadbiran di bawah perundangan untuk bertindak bagi pihak pengguna menjadikan sistem serta kawalan ke atas penggunaan terma dalam kontrak lebih berkesan. Ketiadaan badan dan agensi khas sebagai mewakili pengguna dalam isu terma tidak adil dalam kontrak telah meletakkan pilihan dan beban ke atas bahu pengguna untuk membawa tindakan ke atas pihak industri. Malaysia memerlukan perundangan yang lebih bersifat mesra pengguna bagi memudahkan pengguna memahami haknya serta mewujudkan badan-badan khas seperti di United Kingdom dan Australia untuk perlindungan yang lebih berkesan kepada pengguna bagi menangani isu terma tidak adil dalam kontrak. ${ }^{43}$

Perkara yang turut dikesan sebagai sebahagian daripada kelemahan Bahagian IIIA adalah kekaburan dan ketidakjelasan beberapa perkara dalam peruntukannya. Antaranya adalah berkaitan dengan isu pemakaian Bahagian IIIA, adakah terpakai kepada kepada semua jenis kontrak, termasuk kontrak antara pengguna dan peniaga
(B2C)? Persoalan ini ditimbulkan oleh seksyen 24B yang menyebut bahawa peruntukan-peruntukan Bahagian ini hendaklah terpakai bagi semua kontrak. Walau bagaimanapun, berdasarkan tujuan dan objektif APP 1999 iaitu melindungi pengguna, maka Bahagian IIIA dihujahkan untuk terpakai kepada kontrak pengguna sahaja. ${ }^{44}$ Yang turut menjadi persoalan adalah kekaburan maksud dan huraian kepada beberapa istilah yang disebut dalam Bahagian IIIA, seperti terma "keras", "menindas" dan "tidak berpatutan." 45 Begitu juga dengan ketidakjelasan maksud "tanpa justifikasi kukuh" serta ujian yang seharusnya digunakan oleh mahkamah bagi menentukannya. Perkara-perkara ini tidak dijelaskan oleh Bahagian IIIA, memberikan cabaran kepada mahkamah dan tribunal untuk menentukannya.

Selain peruntukan di bawah APP 1999, Akta Sewa Beli 1967 turut mengadakan kawalan ke atas terma-terma kontrak bentuk seragam dalam perjanjian sewa beli dengan mengadakan peruntukan-peruntukan yang mengehadkan atau melarang penggunaan fasal-fasal tertentu. ASB 1967 menegaskan bahawa mana-mana peruntukan atau terma dalam perjanjian sewa beli yang mengecualikan atau mengehadkan hak-hak penyewa untuk memutuskan perjanjian adalah tidak sah dan tiada kuat kuasa. ${ }^{46}$ Kesan yang sama dikenakan terhadap terma yang mengenakan liabiliti yang lebih besar semasa keputusan perjanjian sewa beli atau bailmen di bawahnya, daripada liabliti yang dia akan tertakluk di bawah perjanjian sewa beli yang diputuskan mengikut ASB 1967. ${ }^{47}$ Selain itu, tuan punya juga tidak boleh memasukkan terma yang menghendaki penyewa membayar faedah terhadap ansuran yang masih belum dibayar pada kadar melebihi lapan peratus setahun bagi perjanjian pada kadar caj terma tetap, manakala bagi perjanjian pada kadar caj terma berubah-ubah, dua peratus melebihi kadar caj terma semasa, faedah biasa yang dikira mengikut harian atau kadar faedah lain yang boleh ditetapkan. Kemasukan terma-terma ini ke dalam perjanjian akan mengakibatkannya menjadi tidak sah atau tiada kuat kuasa. ${ }^{48}$ Tuan punya juga dilarang daripada melepaskan liabilitinya bagi sebarang tindakan atau ingkar oleh sesiapa yang bertindak bagi pihaknya semasa proses perundingan yang membawa kemasukan perjanjian dengan memasukkan peruntukan yang sedemikian. ${ }^{49}$ Peruntukan berhubung dengan larangan terhadap tuan punya untuk mengelakkan liabiliti agen atau orang yang bertindak bagi pihak tuan punya bagi 
representasi, pernyataan atau waranti melalui kemasukan terma diperuntukkan di bawah seksyen 8(2). ${ }^{50}$ Dalam proses pengambilalihan, ASB 1967 turut mengawal kemasukan terma oleh tuan punya bagi mengelakkan liabiliti-liabiliti tertentu. Peruntukan akan menjadi tidak sah atau tiada kuat kuasa sekiranya ia bertujuan untuk memberikan kuasa kepada tuan punya atau orang yang bertindak bagi pihaknya untuk memasuki bangunan bagi mengambil milikan barang-barang selain mengikut peruntukan-peruntukan ASB 1967 atau mereka dilepaskan liabiliti bagi kemasukan tersebut. ${ }^{51}$ Selain itu, mana-mana peruntukan yang menjadikan kuat kuasa perjanjian sewa beli ditentukan atau diubahsuaikan atau mana-mana orang diberi kuasa untuk mengambil milikan semula barang yang terkandung dalam perjanjian sekiranya penyewa menjadi bankrap atau membuat tindakan kebankrapan atau melaksanakan surat ikatan penyerahhakan atau surat ikatan perkiraan turut menjadi tidak sah atau tiada kuat kuasa. ${ }^{52}$ Akhir sekali, mana-mana peruntukan yang dimasukkan bertujuan untuk mengecualikan, mengubah suai atau mengehadkan mana-mana peruntukan ASB 1967 akan menjadi tidak sah atau tiada kuat kuasa melainkan ia diperuntukkan secara nyata oleh Akta. ${ }^{53}$

\section{KESIMPULAN}

Pembentukan kontrak adalah bersandarkan konsep kebebasan yang mana pihak-pihak yang ingin mengikat diri mereka dalam suatu kontrak bebas untuk berunding dan tawar-menawar. Sekiranya mana-mana pihak berasakan sesuatu terma itu tidak adil terhadapnya, rundingan boleh dibuat untuk mengubah atau menolak terma tersebut dan sekiranya pihak yang satu lagi menolak permintaannya, maka dia bebas untuk mengelak daripada memasuki kontrak tersebut. Namun begitu dalam konteks transaksi dalam pasaran moden pada hari ini, adalah janggal dan mustahil untuk mengaitkan konsep ini dalam kontrak bentuk seragam seperti pengambilan polisi insurans atau pembiayaan kenderaan melalui kontrak sewa beli. Hakikatnya, tiada persetujuan nyata antara pihak-pihak yang mana terma-terma dimasukkan oleh satu pihak tanpa perundingan dengan pihak satu lagi. Pengguna tiada pilihan melainkan terpaksa menerima walaupun tidak bersetuju dengan terma-terma tersebut sekiranya mereka inginkan barangan atau produk yang ditawarkan. Dengan justifikasi tentang keperluan kontrak bentuk seragam pada hari ini, kawalan perundangan yang mantap menjadi jawapan kepada isu perlindungan pengguna. Dalam konteks sewa beli, selain terpaksa akur dengan terma yang telah tersedia dalam perjanjian yang ada antaranya bersifat tidak adil, pengguna juga terpaksa berhadapan dengan pelbagai fasal pengecualian, sama ada yang dibenarkan secara nyata oleh undang-undang atau sebaliknya.

Memang tidak dinafikan bahawa dengan wujudnya Bahagian IIIA APP 1999, pengguna kini boleh menarik nafas lega kerana dilindungi di bawah undang-undang daripada terma tidak adil dalam kontrak. Namun begitu, dengan kelompangan dan kelemahan yang telah dibincangkan, sejauh manakah Bahagian IIIA mencapai objektifnya masih diragui. Selain APP 1999, beberapa peruntukan $^{54}$ dalam ASB 1967 turut menyentuh dan mengawal penggunaan terma dalam kontrak sewa beli, namun pemakaiannya amat terhad, iaitu terhadap perkara-perkara yang tertentu sahaja. Malahan, ASB 1967 turut membenarkan penggunaan fasal pengecualian dalam keadaan-keadaan tertentu. ${ }^{55}$ Oleh itu, kawalan melalui ASB 1967 terhadap terma tidak adil dalam perjanjian sewa beli adalah tidak menyeluruh dalam melindungi pengguna. Umumnya, kawalan perundangan ke atas penggunaan terma tidak adil dalam kontrak sewa beli sama ada melalui ASB 1967 mahupun APP 1999 masih memerlukan penambahbaikan bagi memantapkan perlindungan kepada pengguna.

\section{NOTA}

1 V Sinnadurai, Law of Contract, Lexis Nexis, Malaysia, 2011, hlm. 271

2 Abdul Majid, K.Arjunan, Business Law in Malaysia. Lexis Nexis, Malaysia, 2005, hlm. 224

3 D. Slawson, 'Standard Form Contracts and Democratic Control of Lawmaking Power', (1971) 84 Harv L Rev, hlm. 529.

4 G.Howells, I.Ramsay, T. Wilhelmsson, Handbook of Research on International Consumer Law, Edward Elgar Publishing Ltd, UK, 2010. hlm.163.

5 G.Howells, S.Weatherill, Consumer Protection Law, Ashgate Publishing Company, 2005, hlm.287.

6 Sakina, Suzanna, Azimon, Akta Kontrak 1950: Keperluan Semakan Semula, 2011, 1 LNS (A) xv

7 M. Furmston, Cheshire, Fifoot \& Furmston Law of Contract, Oxford University Press, 2006, hlm.21.

8 G.Howells, I.Ramsay, T.Wilhelmsson, Handbook of Research on International Consumer Law, hlm.159.

9 P.S Atiyah, An Introduction to the Law of Contract, Clarendon Press, Oxford, 2002, hlm 314.

10 D. Rosenthal, Guide to Consumer Credit: Law and Practice, Butterworths, London, 1994, hlm. 194. 
11 Crowther Committee : Final Report on Consumer Credit (1971), hlm. 233.

12 S.S.Rachagan, Consumer Law Reform: A Report, Selangor \& Federal Territory Consumers' Association, 1992, hlm.60.

13 B.W. Harvey, D.L.Parry, The Law of Consumer Protection and Fair Trading, Butterworths, London, 1987, hlm.123.

14 (1938) 3 All E.R. 580

15 (1962) All E.R. 385

16 Sakina Shaik Ahmad Yusoff, Suzanna Mohamed Isa, Azimon Abdul Aziz, Ong Tze Chin, Corporate Responsibility via Malaysian Contract Law: A Concern for Consumer Protection. (2012) 20(1): Pertanika Journal, Social Science \& Humanities 227-238 hlm. 228.

17 Fridman, G. H. L. The Law of Contract in Canada. Carswell Thomson Professsional Publishing, Kanada, 1999, hlm 571.

18 G. Borrie, A.L Diamond, The Consumer, Society and The Law, Penguin Books, 1981, hlm 38.

19 Abdul Majid, K.Arjunan, Business Law in Malaysia, Lexis Nexis, Malaysia, 2005, hlm 211.

20 Seksyen 7(2)(b) dan 7(3) ASB1967.

21 Terma tersirat bahawa barangan mempunyai kualiti boleh niaga dan barangan memenuhi tujuan ia diperolehi.

22 Seksyen 7(2)(b) dan 7(3) ASB 1967.

23 Siti Noorafizah Azizan. Remedi Pengguna di bawah Kontrak Sewa-beli Kenderaan Terpakai. Undang-undang dalam Era Teknologi, Fakulti Undang-undang, UKM, Bangi. 2008.

24 Seksyen $34(\mathrm{~g})$

25 I.Ramsay, Consumer Law and Policy, Hart Publishing, USA, 2007, hlm.158.

26 Crowther Committee: Final Report on Consumer Credit, 1971, hlm.233.3e

27 Clarence Edwin, Judicial Interference with Standard Form Contracts: A Critique on Ho Lai Ying v Cempaka Finance Bhd, 2005, 5 MLJ xiii.

28 V. Sinnadurai, Law of Contract, hlm. 271.

29 Diambil daripada Indian Law Commission Report on Unfair (Procedural \& Substantive) Terms in Contract (2006).

30 Peruntukan APP 1999 turut terpakai kepada kontrak sewa beli

31 Seksyen 24A, APP 1999.

32 Pindaan mengambil dan melaksanakan cadangan oleh Indian Law Commission melalui Report on Unfair (Procedural \& Substantive) Terms in Contract.

33 Seksyen 24G(1) APP 1999.

34 Seksyen 24I (1) APP 1999, bagi pertubuhan perbadanan, denda tidak melebihi dua ratus lima puluh ribu ringgit dan bagi kesalahan kedua dan seterusnya, denda tidak melebihi lima ratus ribu ringgit; bagi bukan perbadanan, denda tidak melebihi satu ratus ribu ringgit atau penjara tidak lebih lima tahun atau kedua-duanya, dan bagi kesalahan seterusnya denda tidak melebihi dua ratus lima puluh ribu ringgit atau dipenjara tidak lebih enam tahun, atau kedua-duanya. Bagi kesalahan berterusan, sebagai tambahan, boleh didenda tidak melebihi dua ribu ringgit bagi setiap hari selama mana kesalahan itu berterusan selepas sabitan.

35 Seksyen 3 APP 1999.

36 Seksyen 3 APP 1999.

37 Naemah Amin, 'Protecting Consumers against Unfair Contract Terms in Malaysia: The Consumer Protection (Amendment) Act 2010'. (2013) 1 MLJ lxxxix, xc.

38 Azimon Abd Aziz, Sakina Shaik Ahmad Yusoff, Shamsuddin Suhor, et al, Standard Form Contracts in Consumer Transaction: A Comparaive Study of Selected Asian Countries. (2012) 15. Malaysian Journal of Consumer and Family Economics.
39 Naemah Amin, Protecting Consumers against Unfair Contract Terms in Malaysia: The Consumer Protection (Amendment) Act 2010'. (2013) 1 MLJ lxxxix, xc.

40 Rofah Setyowati, Ong Tze Chin \& Sakina Shaik Ahmad Yusoff, Pelindungan Pengguna di Malaysia, Dalam Sakina Shaik Ahmad Yusoff, Rahmah Ismail \& Shamsuddin Suhor (pnyt), Pengguna dan Undang-Undang, Universiti Kebangsaan Malaysia, Bangi, 2015, hlm 42.

${ }_{41}$ Azimon Abdul Aziz, Sakina Shaik Ahmad Yusoff, Rahmah Ismail, Shamsuddin Suhor, Kartini Aboo Talib@ Khalid \& Muhammad Rizal Razman, Ke Arah Keadilan Sosial Pengguna: Masalah Terma Tidak Adil dalam Kontrak Seragam Pengguna, Dalam Rahmah Ismail, Sakina Shaik Ahmad Yusoff \& Shamsuddin Suhor (pnyt), Undang-Undang Pengguna dan Keadilan Sosial, Universiti Kebangsaan Malaysia, Bangi, 2015, hlm 92.

42 Seperti Office of Fair Trading di United Kingdom dan Australian Competition and Consumer Agency di Australia.

43 Mitra Manisha Rajadurai, Donna Elizabeth Barclay, Unfair Contract Terms in Malaysia: The Gap in the Consumer Protection (Amendment) Act 2010. (2014) 1 LNS (A) xx.

44 V. Sinnadurai, Law of Contract, hlm. 271; Naemah Amin, Protecting Consumers against Unfair Contract Terms in Malaysia: The Consumer Protection (Amendment) Act 2010. (2013) 1 MLJ lxxxix, xc.

45 Seksyen 24D (1) APP 1999.

46 Seksyen 34(a) ASB 1967.

47 Seksyen 34(b) ASB 1967.

48 Seksyen 34(c) ASB 1967.

49 Seksyen 34(d) - peruntukan akan menjadi tak sah dan tiada kuat kuasa.

50 Setiap waad, syarat atau terma dalam mana-mana perjanjian sewa-beli atau dokumen lain yang bertujuan untuk mengecualikan, menghadkan atau mengubahsuai subseksyen (1) atau untuk menghalang apa-apa hak untuk mengambil tindakan atau apa-apa pembelaan yang berdasarkan atau timbul dari mana-mana representasi, waranti atau pernyataan tersebut adalah tak sah. Subseksyen (1) adalah peruntukan berhubung dengan hak penyewa terhadap pemunya dan peniaga bagi salahnyataan semasa proses perundingan yang membawa kepada kemasukan perjanjian.

$51 \quad$ Seksyen 34(e) ASB 1967.

$52 \quad$ Seksyen 34(f) ASB 1967.

$53 \quad$ Seksyen 34(g) ASB 1967.

54 Seksyen 34 (a-g) ASB 1967.

55 Seksyen 7(2(b) dan 7(3) ASB 1967

\section{RUJUKAN}

Abdul Majid, and Arjunan, K. 2005. Business Law in Malaysia. Malaysia: Lexis Nexis.

Atiyah, P. S. 2002. An Introduction to the Law of Contract. Oxford: Clarendon Press.

Azimon Abdul Aziz, Sakina Shaik Ahmad Yusoff, Rahmah Ismail, Shamsuddin Suhor, Kartini Aboo Talib@ Khalid \& Muhammad Rizal Razman. 2015. Ke Arah Keadilan Sosial Pengguna: Masalah Terma Tidak Adil dalam Kontrak Seragam Pengguna, Dalam Rahmah Ismail, Sakina Shaik Ahmad Yusoff \& Shamsuddin Suhor (pnyt). Bangi: Universiti Kebangsaan Malaysia.

Azimon Abdul Aziz, Sakina Shaik Ahmad Yusoff, Shamsuddin Suhor, et al. 2012. Standard Form Contracts in Consumer Transaction: A Comparaive Study of Selected Asian Countries. Malaysian Journal of Consumer and Family Economics, vol 15. 
Borrie, G and Diamond, A. L. 1981. The Consumer, Society and the Law. Penguin Books.

Clarence Edwin. 2005. Judicial Interference with Standard Form Contracts: A Critique on Ho Lai Ying v Cempaka Finance Bhd. 5 MLJ xiii.

Crowther Committee: Final Report on Consumer Credit (1971).

Fridman, G. H. L. 1999. The Law of Contract in Canada. Kanada: Carswell Thomson Professsional Publishing.

Furmston, M. 2006. Cheshire, Fifoot \& Furmston Law of Contract. Oxford University Press.

Sinnadurai, V. 2011. Law of Contract. Malaysia: Lexis Nexis.

Slawson, D. 1971. 'Standard Form Contracts and Democratic Control of Law Making Power'. 84 Harv L Rev.

Harvey, B.W. and Parry, D.L. 1987. The Law of Consumer Protection and Fair Trading. London: Butterworths.

Howells, G, Ramsay, I and Wilhelmsson, T. 2010. Handbook of Research on International Consumer Law. UK: Edward Elgar Publishing Ltd.

Howells, G and Weatherill, S. 2005. Consumer Protection Law. Ashgate Publishing Company.

Mitra Manisha Rajadurai \& Donna Elizabeth Barclay. 2014. Unfair Contract Terms in Malaysia: The Gap in the Consumer Protection (Amendment) Act 2010. 1 LNS (A) $x x$.

Naemah Amin. 2013. Protecting Consumers against Unfair Contract Terms in Malaysia: The Consumer Protection (Amendment) Act 2010. 1 MLJ lxxxix, xc.

Rachagan, S. S. 1992. Consumer Law Reform: A Report. Selangor \& Federal Territory Consumers' Association.
Ramsay, I. 2007. Consumer Law and Policy. USA: Hart Publishing.

Rofah Setyowati, Ong Tze Chin \& Sakina Shaik Ahmad Yusoff, Pelindungan Pengguna di Malaysia. 2015. Dalam Sakina Shaik Ahmad Yusoff, Rahmah Ismail \& Shamsuddin Suhor (pnyt). Pengguna dan Undang-Undang. Bangi: Universiti Kebangsaan Malaysia.

Rosenthal, D. 1994. Guide to Consumer Credit: Law and Practice. London: Butterworths.

Sakina, Suzanna dan Azimon. 2011. Akta Kontrak 1950: Keperluan Semakan Semula. 1 LNS (A) $x v$.

Sakina Shaik Ahmad Yusoff, Suzanna Mohamed Isa, Azimon Abdul Aziz, Ong Tze Chin. 2012. Corporate Responsibility via Malaysian Contract Law: A Concern for Consumer Protection. Pertanika Journal, Social Science \& Humanities 20(1): 227-238

Siti Noorafizah Azizan. 2008. Remedi Pengguna di bawah Kontrak Sewa-beli Kenderaan Terpakai. Undang-undang dalam Era Teknologi. Bangi: Fakulti Undang-undang, UKM.

Siti Noorafizah Azizan

Pensyarah

Fakulti Undang-undang,

Universiti Kebangsaan Malaysia,

43600 Bangi, Selangor.

Email: feez@ukm.edu.my 